\title{
Effecs of Cypermethrin on Some Biochemical Changes in Rats: The Protective Role of Propolis
}

\author{
Gokhan ERASLAN ${ }^{1)}$, Murat KANBUR ${ }^{1)}$, Sibel SILICI ${ }^{2)}$, \\ Sule ALTINORDULU ${ }^{1)}$, and Mursel KARABACAK ${ }^{2)}$ \\ ${ }^{1)}$ Department of Pharmacology and Toxicology, Faculty of Veterinary Medicine, University of \\ Erciyes, Kayseri and ${ }^{2)}$ Department of Animal Science, S. Cikrikcioglu Vocational Collage, \\ University of Erciyes, Kayseri, Turkey
}

\begin{abstract}
Twenty eight female Wistar rats weighing 150-200 g were used in this study and these animals were divided into 4 groups, each comprising 7 rats. The first group served as the control group, and groups 2, 3, and 4 were administered a single dose of $250 \mathrm{mg} / \mathrm{kg} . \mathrm{bw}$ propolis, a single dose of $125 \mathrm{mg} / \mathrm{kg} . \mathrm{bw}\left(1 / 2 L D_{50}\right)$ cypermethrin, and a single dose of 125 $\mathrm{mg} / \mathrm{kg}$.bw cypermethrin followed by a single dose of $250 \mathrm{mg} / \mathrm{kg} . \mathrm{bw}$ propolis $30 \mathrm{~min}$ later, per os using a catheter, respectively. Twenty-four hours after propolis administration, blood and tissue (liver, kidney, and brain) samples were collected. Serum glucose, triglyceride, uric acid, cholesterol, aspartate aminotransferase (AST), alanine aminotransferase (ALT) and alkaline phosphatase (ALP) activities/levels, plasma and tissue malondialdehyde (MDA) levels, and erythrocyte and tissue superoxide dismutase (SOD), catalase (CAT) and glutathione peroxidase (GSH-PX) activities were determined. Compared to group 1, significant increases in plasma and tissue MDA levels and kidney GSH-Px activity, and significant decreases in erythrocyte SOD and CAT, liver SOD and GSH-PX, kidney SOD and brain SOD, CAT and $G S H-P x$ activities were determined in group 3. Compared to group 1, a significant increase in glucose and a significant decrease in triglyceride levels were determined in group 3 . Values pertaining to group 4 were demonstrated to be closer to those of group 1.
\end{abstract}

Key words: biochemical changes, cypermethrin, oxidative stress, propolis, rat

\section{Introduction}

Cypermethrin is a pesticide of the synthetic pyrethroid group, used extensively in the fields of environmental health and agriculture. It is known to act as both a stomach and a contact poison. Its selective toxic effects are related to the neural sodium channels. The metabolism of cypermethrin is quite rapid, and during its metabolism reactive oxygen species (ROS) are generated. These free radicals, which are most active, cause oxidative stress through peroxidation of the lipid membrane. Damage may occur in certain tissues and organs, due to either the free radicals that are generated or the direct effect of the pesticide [13-15, 22, 24, 31]. Cells possess intracellular defense mechanisms to prevent damage by these free radicals. In the enzymatic defense system, antioxidant enzymes play a primary role, and these enzymes convert free radicals into less harmful or harmless compounds

(Received 28 October 2007 / Accepted 6 June 2008)

Address corresponding: G. Eraslan, Department of Pharmacology and Toxicology, Faculty of Veterinary Medicine, University of Erciyes, Kayseri, Turkey 
$[17,18,42]$. Various studies have been conducted on certain substances with antioxidant properties, which are not synthesized in the body, and are taken into the body from the diet $[9,14,15,23,32]$. Propolis is one of these substances. Propolis is a biological material collected by bees from various plants. The mechanism underlying the antioxidant effect of propolis is its high content of flavonoids which scavenge free radicals $[2,19,21,29$, 37, 38].

The present study aimed to evaluate the possible prevention of the toxic effects of cypermethrin, administered as a single dose of $125 \mathrm{mg} / \mathrm{kg}$.bw followed by the administration of a single dose of $250 \mathrm{mg} / \mathrm{kg}$.bw propolis, based on certain biochemical parameters.

\section{Materials and Methods}

\section{Animals}

Twenty-eight female Wistar rats, weighing 150-200 $\mathrm{g}$ were used in this study. Rats were obtained from Experimental Research Center of Erciyes University in Kayseri. The animals were evenly divided into 4 groups, one control group and three experimental groups. The animals were exposed to a $12 \mathrm{~h} \mathrm{light/dark} \mathrm{cycle,} \mathrm{housed}$ at a fixed temperature of $22-24^{\circ} \mathrm{C}$, and provided feed and water ad libitum. Pellet feed containing $23 \%$ crude protein, $7 \%$ crude cellulose and 2,600 kcal $/ \mathrm{kg}$ metabolic energy was given to the animals. The guidelines of Erciyes University Faculty of Veterinary Medicine were followed in the animal experiment, animal care and all protocols.

\section{Extraction, preparation, and analysis of propolis}

The method and procedure described by Bankova et $a l$. [1] for propolis extraction and analyses were used for the adjustment of the gas chromatography-mass spectrometry (GC-MS) device. Turkish propolis obtained from Apis mellifera was used in the present study. The localization of this honeybee species is Kayseri province and Bunyan district in Turkey. Propolis samples were stored at $-20^{\circ} \mathrm{C}$ till processed. Subsequently, $30 \mathrm{~g}$ of crude propolis was incubated in $70 \%$ ethanol at $50^{\circ} \mathrm{C}$ for 3 days. The ethanol extract obtained at the end of this period was filtrated and completely vaporized. Following dissolution in water, it was used for examinations.

\section{Administration of cypermethrin and propolis}

The first group served as the control group (group 1), and was administered $1 \mathrm{ml}$ of soy oil per os. The second group (group 2) was first administered $1 \mathrm{ml}$ of soy oil, and then a single dose of $250 \mathrm{mg} / \mathrm{kg}$.bw propolis in a volume of $1 \mathrm{ml}$ per os. The third group (group 3) was administered a single dose of $125 \mathrm{mg} / \mathrm{kg}$.bw $\left(1 / 2 \mathrm{LD}_{50}\right)$ $[35,41]$ cypermethrin in $1 \mathrm{ml}$ of soy oil per os. Finally, the fourth group (group 4) was first administered a single dose of $125 \mathrm{mg} / \mathrm{kg}$.bw cypermethrin in $1 \mathrm{ml}$ of soy oil per os followed by a single dose of $250 \mathrm{mg} / \mathrm{kg}$.bw propolis in a volume of $1 \mathrm{ml}$ per os, 30 min later. All oral administrations to animals were performed using a catheter.

Collection of blood samples and separation of plasma, serum, and erythrocytes

Twenty-four hours after the administration of propolis, blood was collected from all animals under light ether anesthesia into heparinized, dry tubes. Each tube was centrifuged at 3,000 rpm for $10 \mathrm{~min}$ for the separation of serum, plasma, and blood cells.

\section{Collection and preparation of tissues for analysis}

Immediately after the extraction of the liver, kidney, and brain tissues of the animals, tissues were rinsed in ice-cold de-ionized water and homogenized. Prior to homogenization, the tissues were added to a buffer solution with an adjusted $\mathrm{pH}$ value (1:5). Tissues were homogenized in a cabin full of ice using a homogenizer. The homogenate was transferred into tubes and centrifuged at 20,000 rpm for $1 \mathrm{~h}$. The resulting supernatant was transferred to Eppendorf tubes.

\section{Washing of erythrocytes and haemolysis}

Following the centrifugation of the blood samples collected in heparinized tubes and the separation of plasma, the leucocyte and thrombocyte layer above the blood cells was discarded, and the erythrocyte layer was washed three times with phosphate buffered saline. Subsequently, phosphate buffered saline was added at a volume equal to the erythrocyte sediment, and the mixture was slightly shaken. The erythrocyte sediment, $0.8 \mathrm{ml}$, was haemolysed with $3.2 \mathrm{ml}$ of ice-cold distilled water [43]. 
Analysis of erythrocyte hemoglobin and tissue protein levels

Erythrocyte hemoglobin levels were detected in accordance with the cyanomethaemoglobin method described by Fairbanks and Klee [10]. Protein levels in liver, kidney, and brain tissues were determined in accordance with the method described by Lowry et al. [25] and modified by Miller [30]. The results were expressed as $\mathrm{mgHb} / \mathrm{ml}$ haemolysate and $\mathrm{mg}$-protein/ml homogenate.

Measurement of oxidative stress markers of plasma, tissue, and erythrocytes

Plasma measurements were performed as described by Yoshioka et al. [44]. The method described by Ohkawa et al. [33] was used for the determination of tissue malondialdehyde (MDA) levels in all tissues. The results were calculated in $\mathrm{nmol} / \mathrm{ml}$ and $\mathrm{nmol} / \mathrm{mg}$-protein for MDA levels. Superoxide dismutase (SOD) measurements were performed as described by Sun et al. [40]. Catalase (CAT) activity was measured as described by Luck [26]. Detection of glutathione peroxidase (GSH$\mathrm{Px}$ ) activity was performed in accordance with the method described by Paglia and Valentine [34]. Results were calculated in $\mathrm{U} / \mathrm{mgHb}$ and $\mathrm{U} / \mathrm{mg}$-protein for all antioxidant enzyme activities.

\section{Measurement of biochemical parameters in sera}

The measurements of serum glucose, triglyceride, uric acid, cholesterol, aspartate aminotransferase (AST), alanine aminotransferase (ALT), and alkaline phosphatase (ALP) activities/levels were performed automatically by means of a Konelab 60i auto-analyser (Thermo Clinical Labsystems, Finland) using a Konelab label kit (Thermo Clinical Labsystems, Finland).

\section{Statistical analysis}

Statistical analyses were performed with the SPSS 11.0 statistical software package for Windows. Data were calculated as arithmetical means and standard deviations. Significances between groups were evaluated using oneway analysis of variance (ANOVA) with statistical significance set to $P<0.05$. Differences between groups were determined by Duncan's multiple range test.

Results

\section{Propolis composition}

Propolis is composed of fatty and aromatic acids (9-octadecenoic acid, 2-propenoic acid, caffeic acid), alcohol, ketone and terpens (2-naphtalenemethanol, 2-propen-1-one, 4H-1-benzopyran-4-one, coumaran-5,6diol-3-one, benzofuran-3-one), flavonoids (chrysin), esters (cinnamyl cinnamate), and other chemicals (1-phenathrenecarboxy-aldehyde, benzeneamine, eicosane, heptacosane, cyclotrisiloxane). The ion current (TIC \%) and retention time (RT) values of these compounds are given in Table 1 .

\section{Oxidative stress markers}

First, compared to group 1, in group 3, the plasma MDA level was determined to be significantly increased, whereas in group 4, the MDA level was demonstrated to be lower than that of group 3. In other words, the MDA level was determined to be closer to that of group 1 . Tissue MDA levels were determined to be significantly increased in group 3. On the other hand, a decrease in tissue MDA levels was observed in group 4, but no statistically significant difference was found between groups 3 and 4. Second, compared to group 1, the SOD activities of erythrocytes, liver, kidney, and brain tissues were determined to be significantly decreased in group 3 . Those of group 4 were demonstrated to be closer to those of group 1, and as a result there was no significant difference between groups 1 and 4. Third, compared to group 1, in group 3, CAT activity was demonstrated to have decreased significantly in erythrocytes and brain tissue, whereas in group 4 these values were demonstrated to be closer to those of group 1. Fourth, statistically significant differences in the GSH-Px activities of liver, kidney, and brain tissues were determined in group 3 compared to group 1 . There were decreases in the enzyme activities of brain and liver tissues and an increase in that of kidney tissue. Enzyme activities of group 4 were close to those of group 1. Lastly, compared to the control group, no significant differences existed with respect to oxidative stress markers (MDA, SOD, CAT, and GSH-Px) in group 2 (Tables 2-5). 
Table 1. Chemical composition of the ethanol extract of the propolis sample

\begin{tabular}{llcc}
\hline \multicolumn{2}{c}{ Compounds } & \% TIC & RT (min) \\
\hline Fatty and aromatic acids & 9-Octadecenoic acid & 1.46 & 25.22 \\
& 2-Propenoic acid & 4.88 & 27.53 \\
& Caffeic acid & 3.45 & 29.19 \\
Alcohol, ketone, and terpens & 2-Naphtalenemethanol & 0.90 & 15.24 \\
& 2-Propen-1-one & 8.81 & 29.85 \\
& 4H-1-Benzopyran-4-one & 6.73 & 31.29 \\
& Coumaran-5,6-diol-3-one & 0.87 & 33.53 \\
Flavonoids & Benzofuran-3-one & 2.94 & 35.19 \\
Esters & Chrysin & 10.62 & 34.38 \\
Others & Cinnamyl cinnamate & 3.21 & 30.00 \\
& 1-Phenathrenecarboxy-aldehyde & 0.92 & 25.97 \\
& Benzeneamine & 1.67 & 26.60 \\
& Eicosane & 3.88 & 37.15 \\
& Heptacosane & 7.97 & 34.32 \\
& Cyclotrisiloxane & 0.80 & 35.96 \\
\hline
\end{tabular}

RT: Retention time. \%TIC: \% of the ion current, GC-MS. The ion current generated depends on the characteristics of the compound concerned and it is not a true quantitative value.

Table 2. Plasma MDA level and erythrocyte SOD, CAT, and GSH-Px activities in the control and experimental groups

\begin{tabular}{lcccc}
\hline Groups* & $\begin{array}{c}\text { MDA } \\
(\mathrm{nmol} / \mathrm{ml})\end{array}$ & $\begin{array}{c}\text { SOD } \\
(\mathrm{U} / \mathrm{mgHb})\end{array}$ & $\begin{array}{c}\text { CAT } \\
(\mathrm{U} / \mathrm{mgHb})\end{array}$ & $\begin{array}{c}\text { GSH-Px } \\
(\mathrm{U} / \mathrm{mgHb})\end{array}$ \\
\hline Group 1 & $2.47 \pm 0.35^{\mathrm{a}}$ & $1.87 \pm 0.21^{\mathrm{a}}$ & $0.48 \pm 0.07^{\mathrm{a}}$ & $0.65 \pm 0.19^{\mathrm{a}, \mathrm{b}}$ \\
Group 2 & $2.54 \pm 0.82^{\mathrm{a}}$ & $1.81 \pm 0.47^{\mathrm{a}}$ & $0.46 \pm 0.11^{\mathrm{a}}$ & $0.70 \pm 0.20^{\mathrm{a}}$ \\
Group 3 & $3.80 \pm 0.38^{\mathrm{b}}$ & $1.36 \pm 0.12^{\mathrm{b}}$ & $0.26 \pm 0.08^{\mathrm{b}}$ & $0.42 \pm 0.11^{\mathrm{b}}$ \\
Group 4 & $3.42 \pm 0.60^{\mathrm{b}}$ & $1.50 \pm 0.20^{\mathrm{a}, \mathrm{b}}$ & $0.37 \pm 0.03^{\mathrm{a}, \mathrm{b}}$ & $0.60 \pm 0.15^{\mathrm{a}, \mathrm{b}}$ \\
\hline
\end{tabular}

Data: arithmetical mean $\pm \mathrm{SD}$. *: Group 1, control; group 2, propolis; group 3, cypermethrin; group 4, cypermethrin plus propolis. ${ }^{\mathrm{a}, \mathrm{b}}$ : Data within the same column are significantly different $(P<0.05)$, if they do not share the same letters.

Table 3. Liver MDA level and SOD, CAT, and GSH-Px activities in the control and experimental groups

\begin{tabular}{lcccc}
\hline Groups & $\begin{array}{c}\text { MDA } \\
(\text { nmol/mg-protein })\end{array}$ & $\begin{array}{c}\text { SOD } \\
(\text { U/mg-protein })\end{array}$ & $\begin{array}{c}\text { CAT } \\
(\text { U/mg-protein })\end{array}$ & $\begin{array}{c}\text { GSH-Px } \\
(\text { U/mg-protein })\end{array}$ \\
\hline Group 1 & $2.97 \pm 0.74^{\mathrm{a}}$ & $2.92 \pm 0.88^{\mathrm{a}}$ & $0.37 \pm 0.14^{\mathrm{a}, \mathrm{b}}$ & $3.20 \pm 0.51^{\mathrm{a}}$ \\
Group 2 & $2.83 \pm 0.77^{\mathrm{a}}$ & $3.07 \pm 0.24^{\mathrm{a}}$ & $0.42 \pm 0.12^{\mathrm{a}}$ & $3.10 \pm 0.81^{\mathrm{a}}$ \\
Group 3 & $5.12 \pm 1.02^{\mathrm{b}}$ & $1.77 \pm 0.72^{\mathrm{b}}$ & $0.20 \pm 0.06^{\mathrm{b}}$ & $1.83 \pm 0.52^{\mathrm{b}}$ \\
Group 4 & $4.30 \pm 0.90^{\mathrm{a}, \mathrm{b}}$ & $2.40 \pm 0.40^{\mathrm{a}, \mathrm{b}}$ & $0.30 \pm 0.09^{\mathrm{a}, \mathrm{b}}$ & $2.44 \pm 0.67^{\mathrm{a}, \mathrm{b}}$ \\
\hline
\end{tabular}

Data: arithmetical mean $\pm \mathrm{SD}$. ${ }^{\mathrm{a}, \mathrm{b}}$ : Data within the same column are significantly different $(P<0.05)$, if they do not share the same letters.

\section{Serum biochemical parameters}

First, significant differences were demonstrated to exist among the groups for glucose levels. In group 3, the serum glucose level was demonstrated to have increased significantly. On the other hand, the serum glucose level of group 4 was demonstrated to be close to that of group 1. Second, compared to group 1, triglyceride levels were determined to be significantly decreased in group 3. Those of group 4 were demonstrated to be closer to those of group 1 . Third, in comparison to group 
Table 4. Kidney MDA level and SOD, CAT, and GSH-Px activities in the control and experimental groups

\begin{tabular}{lcccc}
\hline Groups & $\begin{array}{c}\text { MDA } \\
(\text { nmol/mg-protein })\end{array}$ & $\begin{array}{c}\text { SOD } \\
(\text { U/mg-protein) }\end{array}$ & $\begin{array}{c}\text { CAT } \\
(\text { U/mg-protein })\end{array}$ & $\begin{array}{c}\text { GSH-Px } \\
(\text { U/mg-protein })\end{array}$ \\
\hline Group 1 & $3.04 \pm 1.04^{\mathrm{a}}$ & $3.13 \pm 0.90^{\mathrm{a}}$ & $0.55 \pm 0.14^{\mathrm{a}}$ & $3.60 \pm 0.82^{\mathrm{a}}$ \\
Group 2 & $2.96 \pm 0.17^{\mathrm{a}}$ & $3.21 \pm 0.67^{\mathrm{a}}$ & $0.59 \pm 0.14^{\mathrm{a}}$ & $3.40 \pm 0.23^{\mathrm{a}}$ \\
Group 3 & $4.99 \pm 1.09^{\mathrm{b}}$ & $1.81 \pm 0.59^{\mathrm{b}}$ & $0.30 \pm 0.07^{\mathrm{a}, \mathrm{b}}$ & $6.12 \pm 0.48^{\mathrm{c}}$ \\
Group 4 & $3.81 \pm 1.22^{\mathrm{a}, \mathrm{b}}$ & $2.63 \pm 0.56^{\mathrm{a}, \mathrm{b}}$ & $0.44 \pm 0.10^{\mathrm{b}}$ & $4.84 \pm 0.52^{\mathrm{b}}$ \\
\hline
\end{tabular}

Data: arithmetical mean $\pm \mathrm{SD}$. ${ }^{\mathrm{a}, \mathrm{b}, \mathrm{c}}$ : Data within the same column are significantly different $(P<0.05)$, if they do not share the same letters.

Table 5. Brain MDA level and SOD, CAT, and GSH-Px activities in the control and experimental groups

\begin{tabular}{lcccc}
\hline Groups & $\begin{array}{c}\text { MDA } \\
\text { (nmol/mg-protein) }\end{array}$ & $\begin{array}{c}\text { SOD } \\
(\text { U/mg-protein) }\end{array}$ & $\begin{array}{c}\text { CAT } \\
(\text { U/mg-protein })\end{array}$ & $\begin{array}{c}\text { GSH-Px } \\
(\text { U/mg-protein) }\end{array}$ \\
\hline Group 1 & $9.00 \pm 1.70^{\mathrm{a}}$ & $6.90 \pm 1.93^{\mathrm{a}}$ & $2.78 \pm 0.70^{\mathrm{a}}$ & $6.84 \pm 1.30^{\mathrm{a}}$ \\
Group 2 & $9.27 \pm 0.69^{\mathrm{a}}$ & $6.57 \pm 0.56^{\mathrm{a}}$ & $2.95 \pm 0.51^{\mathrm{a}}$ & $6.08 \pm 1.45^{\mathrm{a}, \mathrm{b}}$ \\
Group 3 & $14.74 \pm 2.29^{\mathrm{b}}$ & $3.67 \pm 1.38^{\mathrm{b}}$ & $1.80 \pm 0.34^{\mathrm{b}}$ & $4.09 \pm 1.16^{\mathrm{b}}$ \\
Group 4 & $12.88 \pm 3.18^{\mathrm{a}, \mathrm{b}}$ & $5.09 \pm 0.57^{\mathrm{a}, \mathrm{b}}$ & $2.34 \pm 0.42^{\mathrm{a}, \mathrm{b}}$ & $5.17 \pm 1.69^{\mathrm{a}, \mathrm{b}}$ \\
\hline
\end{tabular}

Data: arithmetical mean $\pm \mathrm{SD}$. ${ }^{\mathrm{a}, \mathrm{b}}$ : Data within the same column are significantly different $(P<0.05)$, if they do not share the same letters.

Table 6. Serum glucose, triglyceride, uric acid, and cholesterol levels in the control and experimental groups

\begin{tabular}{lcccc}
\hline Groups & $\begin{array}{c}\text { Glucose } \\
(\mathrm{mg} / \mathrm{dL})\end{array}$ & $\begin{array}{c}\text { Triglyceride } \\
(\mathrm{mg} / \mathrm{dL})\end{array}$ & $\begin{array}{c}\text { Uric Acid } \\
(\mathrm{mg} / \mathrm{dL})\end{array}$ & $\begin{array}{c}\text { Cholesterol } \\
(\mathrm{mg} / \mathrm{dL})\end{array}$ \\
\hline Group 1 & $173.57 \pm 39.31^{\mathrm{a}}$ & $94.57 \pm 32.18^{\mathrm{a}}$ & $2.18 \pm 0.41$ & $82.85 \pm 8.09^{\mathrm{a}, \mathrm{b}}$ \\
Group 2 & $161.57 \pm 20.25^{\mathrm{a}}$ & $85.42 \pm 23.91^{\mathrm{a}}$ & $2.20 \pm 0.62$ & $73.85 \pm 6.30^{\mathrm{a}}$ \\
Group 3 & $243.85 \pm 76.77^{\mathrm{b}}$ & $54.42 \pm 12.59^{\mathrm{b}}$ & $2.62 \pm 1.28$ & $86.57 \pm 5.62^{\mathrm{b}}$ \\
Group 4 & $198.00 \pm 56.80^{\mathrm{a}, \mathrm{b}}$ & $94.57 \pm 20.04^{\mathrm{a}}$ & $2.70 \pm 0.25$ & $89.71 \pm 7.65^{\mathrm{b}}$ \\
\hline
\end{tabular}

Data: arithmetical mean \pm SD. ${ }^{a, b}$ : Data within the same column are significantly different $(P<0.05)$, if they do not share the same letters.

Table 7. Serum AST, ALT, and ALP activities in the control and experimental groups

\begin{tabular}{lcrc}
\hline Groups & AST $(\mathrm{U} / \mathrm{L})$ & \multicolumn{1}{c}{ ALT $(\mathrm{U} / \mathrm{L})$} & ALP $(\mathrm{U} / \mathrm{L})$ \\
\hline Group 1 & $375.57 \pm 102.07$ & $117.00 \pm 27.25$ & $374.85 \pm 91.39$ \\
Group 2 & $367.28 \pm 67.13$ & $110.00 \pm 24.52$ & $382.00 \pm 74.14$ \\
Group 3 & $294.57 \pm 93.72$ & $97.57 \pm 33.67$ & $423.57 \pm 70.68$ \\
Group 4 & $333.42 \pm 108.05$ & $129.57 \pm 35.71$ & $366.14 \pm 30.10$ \\
\hline
\end{tabular}

Data: arithmetical mean \pm SD. Data within the same column aren't significantly different $(P>0.05)$.

2, statistically significant differences were determined in groups 3 and 4 for cholesterol levels. The values were determined to have increased in groups 3 and 4 . However, when compared to group 1, no significant difference was determined. Lastly, no statistically significant difference was determined among the groups for uric acid levels and AST, ALT, and ALP activities. In addition, no statistical difference existed between groups 1 and 2 for any of the biochemical parameters (Tables 6 and 7). 


\section{Discussion}

Studies have been conducted on animals to investigate oxidative damage and tissue and organ damage caused by cypermethrin. In these studies, oxidative stress markers and other biochemical parameters [7, 13, 22, 27, 31], and changes in these parameters upon the administration of detoxifying substances have been investigated $[8,14$, $15,24,45]$. However, no previous studies related to effectiveness of propolis against acute cypermethrin exposure exist.

\section{Composition of propolis}

Chrysin which belongs to the group of flavonoids has been defined as an antioxidant component of propolis by Gomez-Romero et al. [16]. Chaudhuri et al. [4] have also reported its antioxidant effects.

\section{Administration of propolis alone}

The changes in MDA levels in the group which was administered propolis alone compared to the control group were statistically insignificant. There were bidirectional changes in antioxidant enzyme activities, yet these changes were also statistically insignificant, demonstrating that the administration of propolis alone has no effects on rats. On the other hand, in a human study carried out by Jasprica et al. [21], propolis was reported to cause a decrease in the MDA level and an increase in SOD activity. Both the origin and composition of propolis are considered to be reasons why similar results were not obtained in the present study. However, even more important, might be the duration of exposure, as only a single administration was performed in the present study. The exposure dose and the physiological features of the animal species used may also have had an effect. Serum glucose, triglyceride and cholesterol levels were determined to have decreased in group 2, yet this decrease was found to be statistically insignificant compared to the control group. This result, as indicated above, may be related to the dose administered and the single administration. As in a study conducted by Matsui et al. [28] with rats, propolis was determined to cause a decrease in glucose levels, and also Fuliang et al. [12] reported it decreased triglyceride and cholesterol levels in rats.

\section{Administration of cypermethrin alone}

The increase of plasma and tissue (liver, kidney, brain) MDA levels and changes in erythrocyte and tissue (liver, kidney, brain) SOD, CAT, and GSH-Px activities were demonstrative of oxidative stress in group 3. Cypermethrin has been determined to accelerate the generation of free radicals, and the increase in free radicals has been demonstrated to cause both an increase in the MDA level through peroxidation of the lipid membrane, and the induction/inhibition of antioxidant enzymes which are involved in the formation and degradation of $\mathrm{H}_{2} \mathrm{O}_{2}$ $[15,27,31]$. These changes may either be directly caused by cypermethrin, or may develop upon the degradation and conversion of the free radicals generated by cypermethrin into less harmful metabolites. Previous studies [13, 15, 22] report cypermethrin causes changes in oxidative stress markers.

Of the biochemical parameters investigated in this study, glucose was determined to have significantly increased in group 3. On the other hand, a significant decrease was demonstrated in the triglyceride level. An increase in blood glucose level is induced by many pesticides, and leads to an increase in the secretion of corticotrophin from the adrenal glands, a decrease in the secretion of insulin, and an increase in the secretion of glucagons [6] and pancreatic damage [20]. A decrease in the triglyceride level may suggest impairment of the lipid metabolism by cypermethrin, since cypermethrin is known to impair lipid metabolism [36]. Increases of blood AST, ALT, and ALP activities are related to liver damage and change in hepatic function [5,11]. Serum ALP activity increases in case of damage to hepatic cells and obstruction of the bile ducts through proliferation of hepatic cells [8]. In the present study, statistically insignificant changes were observed in AST, ALT, and ALP activities, suggesting there was no severe liver damage. Also, there were insignificant changes in uric acid levels. Thus, this can not point out possible toxic effect of cypermethrin in rats.

\section{Administration of cypermethrin plus propolis}

The four oxidative stress markers displayed more normal values in group 4 . The values of these parameters were determined to be close to those of group 1. This suggests propolis caused a decrease in the level of free 
radicals, an effect generated by certain compounds found in the composition of propolis, especially flavonoids. Flavonoids act, particularly, on the xanthine oxidase system and super oxide anion radicals. They also exhibit radical-scavenging activity. Likewise, caffeic acid derivatives have also been indicated as xanthine oxidase inhibitors [3,39]. Matsushige et al. [29] investigated the effect of Brazilian propolis on the free radical, 1,1-diphenyl-2-picrylhydrazyl (DPPH), and the on xanthine/ xanthine oxidase (XOD) and $\alpha$-nicotinamide adenine dinucleotide (NADH)/phenazyne (PMS) reaction which is involved in the production of the superoxide anion radical. They reported that propolis exhibits a strong antioxidant effect. In the present study, compared to group 1, only changes in CAT and GSH-Px activities in the kidney tissue were determined to be significant. No significant changes were determined in any of the other three enzymes investigated. This suggests that changes in enzyme activities are related to a decrease in the level of free radicals. Studies have been carried out on the role of antioxidant components in the detoxification of cypermethrin [15] and other pesticides and their positive effects $[9,23,32]$ on oxidative stress parameters.

The serum biochemical parameters of group 4 were close to these of group 1, and the lack of statistically significant differences between the two groups for glucose and triglyceride levels, which are particularly important parameters, suggests that the administration of propolis had beneficial effects on biochemical parameters after cypermethrin insult. In previous studies, the influence of cypermethrin on biochemical parameters in various animal species, and those of detoxifying substances used for the alleviation of intoxication arising from the pesticides have been investigated. The detoxifying substances were determined to have had positive effects on these parameters $[8,45]$. In the present study, propolis, which has not previously been used as a detoxifier, was demonstrated to display beneficial effects on most of these parameters, by returning their values close to those of the control group after cypermethrin insult.

In conclusion, a single administration of cypermethrin to rats of $125 \mathrm{mg} / \mathrm{kg}$.bw caused changes in some blood and tissue biochemical parameters, and a single administration of propolis of $250 \mathrm{mg} / \mathrm{kg}$.bw exerted a beneficial effect on these parameters.

\section{References}

1. Bankova, V., Popova, M., Bogdanov, S., and Sabatini, AG. 2002. Chemical composition of European propolis: expected and unexpected results. Z. Naturforsch., $C, J$. Biosci. 57: 530-533.

2. Banskota, A.H., Tezuka, Y., and Kadota, S. 2001. Recent progress in pharmacological research of propolis. Phytother. Res. 15: 561-571.

3. Beyer, G. and Melzig, M.F. 2003. Effects of selected flavonoids and caffeic acid derivatives on hypoxanthinexanthine oxidase-induced toxicity in cultivated human cells. Planta Med. 69: 1125-1139.

4. Chaudhuri, S., Banerjee, A., Basu, K., Sengupta, B., and Sengupta, P.K. 2007. Interaction of flavonoids with red blood cell membrane lipids and proteins: antioxidant and antihemolytic effects. Int. J. Biol. Macromol. 41: 42-48.

5. Choudhary, N., Sharma, M., Verma, P., and Joshi, S.C. 2003. Hepato and nephrotoxicity in rat exposed to endosulfan. J. Environ. Biol. 24: 305-308.

6. Datta, M. and Kaviraj, A. 2003. Ascorbic acid supplementation of diet for reduction of deltamethrin induced stress in freshwater catfish Clarias gariepinus. Chemosphere 53: 883-888.

7. Dobsikova, R., Velisek, J., Wlasow, T., Gomulka, P., Svobodova, Z., and Novotny, L. 2006. Effects of cypermethrin on some haematological, biochemical and histopathological parameters of common carp (Cyprinus carpio L.). Neuro. Endocrinol. Lett. 27: 91-95.

8. El-Demerdash, F.M., Yousef, M.I., and Al-Salhen, K.S. 2003. Protective effects of isoflavone on some biochemical parameters affected by cypermethrin in male rabbits. $J$. Environ. Sci. Health B. 38: 365-378.

9. Eraslan, G., Saygi, S., Essiz, D., Aksoy, A., Gul, H., and Macit, E. 2007. Evaluation of aspect of some oxidative stress parameters using vitamin E, proanthocyanidin and $\mathrm{N}$-acetylcycteine against exposure to cyfluthrin in mice. Pestic. Biochem. Physiol. 88: 43-49.

10. Fairbanks, V.F. and Klee, G.G. 1987. Biochemical aspect of hematology. pp. 803-806. In: Fundamentals of Clinical Chemistry, 3rd ed. (Tietz, N.W. ed.), W.B. Saunders, Philadelphia.

11. Filazi, A., Sireli, M., and Kalkan, F. 2003. The influence of amitraz on biochemical parameters in mice. Hum. Exp. Toxicol. 22: 99-101.

12. Fuliang, H.U., Hepburn, H.R., Xuan, H., Chen, M., Daya, S., and Radloff, S.E. 2005. Effects of propolis on blood glucose, blood lipid and free radicals in rats with diabetes mellitus. Pharmacol. Res. 51: 147-152.

13. Gabbianelli, R., Falcioni, G., Nasuti, C., and Cantalamessa, F. 2002. Cypermethrin-induced plasma membrane perturbation on erythrocytes from rats: reduction of fluidity in the hydrophobic core and in glutathione peroxidase activity. Toxicology 175: 91-101.

14. Gabbianelli, R., Nasuti, C., Falcioni, G., and Cantalamessa, F. 2004. Lymphocyte DNA damage in rats exposed to pyrethroids: effect of supplementation with Vitamins E and C. Toxicology 203: 17-26. 
15. Giray, B., Gurbay, A., and Hincal, F. 2001. Cypermethrininduced oxidative stress in rat brain and liver is prevented by vitamin E or allopurinol. Toxicol. Lett. 118: 139-146.

16. Gómez-Romero, M., Arráez-Román, D., Moreno-Torres, R., García-Salas, P., Segura-Carretero, A., and FernándezGutiérrez, A. 2007. Antioxidant compounds of propolis determined by capillary electrophoresis-mass spectrometry. J. Sep. Sci. 30: 595-603.

17. Halliwell, B. 1999. Antioxidant defence mechanisms: from the beginning to the end (of the beginning). Free Radic. Res. 31: 261-272.

18. Halliwell, B. and Chirico, S. 1993. Lipid Peroxidation: its mechanism, measurement, and significance. Am. J. Clin. Nutr. 57: 715-724.

19. Ichikawa, H., Satoh, K., Tobe, T., Yasuda, I., Ushio, F., Matsumoto, K., Endo, K., and Ookubo, C. 2002. Free radical scavenging activity of propolis. Redox Rep. 7: 347-350.

20. Ikizceli, I., Yurumez, Y., Avsarogullari, L., Kucuk, C., Sozuer, E.M., Soyuer, I., Yavuz, Y., and Muhtaroglu, S. 2005. Effect of interleukin-10 on pancreatic damage caused by organophosphate poisoning. Regul. Toxicol. Pharmacol. 42: 260-264.

21. Jasprica, I., Mornar, A., Debeljak, Z., Smolcić-Bubalo, A., Medić-Sarić, M., Mayer, L., Romić, Z., Bućan, K., Balog, T., Sobocanec, S., and Sverko, V. 2007. In vivo study of propolis supplementation effects on antioxidative status and red blood cells. J. Ethnopharmacol. 110: 548-554.

22. Kale, M., Rathore, N., John, S., and Bhatnagar, D. 1999. Lipid peroxidative damage on pyrethroid exposure and alterations in antioxidant status in rat erythrocytes: a possible involvement of reactive oxygen species. Toxicol. Lett. 105: 197-205.

23. Kalender, S., Kalender, Y., Ogutcu, A., Uzunhisarcikli, M,. Durak, D., and Acikgoz, F. 2004. Endosulfan-induced cardiotoxicity and free radical metabolism in rats: the protective effect of vitamin E. Toxicology 202: 227-235.

24. Khan, S.M. 2006. Protective effect of black tea extract on the levels of lipid peroxidation and antioxidant enzymes in liver of mice with pesticide-induced liver injury. Cell Biochem. Funct. 24: 327-332.

25. Lowry, O.H., Rosebrough, N.J. Farr, A.L., and Randall, R.J. 1951. Protein measurement with the folin phenol reagent. J. Biol. Chem. 193: 265-275.

26. Luck, H. 1965. Catalase. pp. 885-894. In: Methods of Enzymatic Analysis (Bergmeyer, H. ed.), Academic Press, New York.

27. Manna, S., Bhattacharyya, D., Mandal, T.K., and Das, S. 2004. Repeated dose toxicity of alfa-cypermethrin in rats. J. Vet. Sci. 5: 241-245.

28. Matsui, T., Ebuchi, S., Fujise, T., Abesundara, K.J., Doi, S., Yamada, H., and Matsumoto, K. 2004. Strong antihyperglycemic effects of water-soluble fraction of Brazilian propolis and its bioactive constituent, 3,4,5-tri-Ocaffeoylquinic acid. Biol. Pharm. Bull. 27: 1797-1803.

29. Matsushige, K., Kusumato, I.T., Yamamoto, Y., Kadota, S., and Namba, T. 1995. Quality evaluation of propolis. 1. a comparative study on radical scavenging effects of propolis and vespae nidus. J. Trad. Med. 12: 45-53.

30. Miller, G.L. 1959. Protein determination for large numbers of samples. Anal. Chem. 31: 964.

31. Nasuti, C., Cantalamessa, F., Falcioni, G., and Gabbianelli, R. 2003. Different effects of Type I and Type II pyrethroids on erythrocyte plasma membrane properties and enzymatic activity in rats. Toxicology 191: 233-244.

32. Ogutcu, A., Uzunhisarcikli, M., Kalender, S., Durak, D., Bayrakdar, F., and Kalender, Y. 2006. The effects of organophosphate insecticide diazinon on malondialdehyde levels and myocardial cells in rat heart tissue and protective role of vitamin E. Pestic. Biochem. Physiol. 86: 93-98.

33. Ohkawa, H., Ohishi, N., and Yagi, K. 1978. Reaction of linoleic acid hydroperoxide with thiobarbutiric acid. $J$. Lipid Res. 19: 1053-1057.

34. Paglia, P.E. and Valentine, W.N. 1967. Studies on the quantitative and qualitative characterization of erythrocyte glutathione peroxidase. J. Lab. Clin. Med. 70: 158-169.

35. Ray, D.E. 1991. Pesticides derived from plants and other organisms. pp. 2-3. In: Handbook of Pesticide Toxicology (Hayes, W.J. Jr. and Laws, E.R. Jr., eds.), Academic Press, New York.

36. Reddy, A.T., Ayyanna, K., and Yellamma, K. 1991. Cypermethrin induced modulations in lipid metabolism of freshwater teleost, Tilapia mossambica. Biochem. Int. 23: 963-967.

37. Russo, A., Longo, R., and Vanella, A. 2002. Antioxidant activity of propolis: role of caffeic acid phenethyl ester and galangin. Fitoterapia 73: 21-29.

38. Sobocanec, S., Sverko, V., Balog, T., Sarić, A., Rusak, G., Likić, S., Kusić, B., Katalinić, V., Radić, S., and Marotti T. 2006. Oxidant/antioxidant properties of Croatian native propolis. J. Agric. Food Chem. 54: 8018-8026.

39. Sud'ina, G.F., Mirzoeva, O.K., Pushkareva, M.A., Korshunova, G.A., Sumbatyan, N.V., and Varfolomeev, S.D. 1993. Caffeic acid phenethyl ester as a lipoxygenase inhibitor with antioxidant properties. FEBS Lett. 329: 21-24.

40. Sun, Y., Oberley, L.W., and Li, Y. 1988. Simple method for clinical assay of superoxide dismutase. Clin. Chem. 34: 497-500.

41. U.S. Environmental Protection Agency. 1989. Pesticide Fact Sheet Number 199: Cypermethrin. pp. 2-9. Office of Pesticides and Toxic Substances, Washington, DC.

42. Valenzuela, A. 1991. The biological significance of malondialdehyde determination in the assessment of tissue oxidative stress. Life Sci. 48: 301-309.

43. Winterbourn, C.C., Hawkins, R.E., Brain, M., and Carrell, R.W. 1975. The estimation of red cell superoxide dismutase activity. J. Lab. Clin. Med. 85: 337-341.

44. Yoshioka, T., Kawada, K., Shimada, T., and Mori, M. 1979. Lipid peroxidation in maternal and cord blood and protective mechanism against activated-oxygen toxicity in the blood. Am. J. Obstet. Gynecol. 135: 372-376.

45. Yousef, M.I., El-Demerdash, F.M., Kamel, K.I., and AlSalhen, K.S. 2003. Changes in some hematological and biochemical indices of rabbits induced by isoflavones and cypermethrin. Toxicology 189: 223-234. 